DOI: 10.32089/WBH.phw.2019.2(268).0001

orcid.org/0000-0003-2192-933X

MICHAE DUdZIŃSKI

\title{
Służba rycerska i mieszczańska oraz jej uzbrojenie na Górnych Łużycach za czasów Luksemburgów. Stan badań
}

Utworzenie Związku Sześciu Miast dało podwaliny pod nie tylko odrębny podmiot polityczny, ale także region geograficzny - Górne Łużyce. Choć ta kraina nie ma obecnie własnej jednostki administracyjnej, a jedynie leży na terytorium województwa dolnośląskiego po polskiej stronie i kraju związkowego Saksonia po niemieckiej, to świadomość jej istnienia jest wciąż żywa wśród zamieszkującej ją ludności. Taki stan rzeczy nie byłby rzecz jasna możliwy, gdyby nie funkcjonujące na terenie Związku Sześciu Miast organy władzy, w tym interesująca nas organizacja militarna. W niniejszym artykule chciałbym przybliżyć stan badań, ponieważ powstało kilka studiów poświęconych tym zagadnieniom, jednak do tej pory nie pojawiła się żadna publikacja, która ujęłaby je całościowo. Jest to wynik stosunkowo słabo rozwiniętego stanu wiedzy nad dziejami kraju nad górnym biegiem Nysy Łużyckiej¹. Dla mocniejszego podkreślenia potrzeby powstania takiego opracowania opisany zostanie nie tylko dotychczasowy dorobek naukowy, ale również baza źródłowa.

$\mathrm{Na}$ wstępie należy poruszyć kilka spraw dotyczących kwestii zasadności podjęcia tej problematyki oraz chronologii i terminologii. Czasy panowania królów czeskich z dynastii Luksemburgów są bardzo znaczące w dziejach Górnych Łużyc, to dzięki nim powstał Związek Sześciu Miast, jeden z najtrwalszych w dziejach I Rzeszy podmiotów politycznych. Z perspektywy badawczej okres ten jest też najbardziej uchwytny źródłowo w porównaniu

$\mathrm{Na}$ ten temat wypowiada się J. Bahlcke, Górne Łużyce. Historyczna kraina, regionalna świadomość i dziejopisarstwo od średniowiecza do XX wieku [w:] Dzieje Górnych Łużyc. Władza, społeczeństwo i kultura od średniowiecza do końca XX wieku, red. J. Bahlcke, tłum. M. Słoń, Warszawa 2007, s. 20-65. 
z wcześniejszymi odcinkami czasu w średniowieczu, możemy bowiem dokładniej przyjrzeć się służbie wojskowej i ewolucji form uzbrojenia w praktyce, które ze względu na rozmiar i charakter bazy źródłowej są dobrze opisane. Do tej bazy należą bowiem nie tylko zapisy kronikarskie, ale również rachunki miejskie. W szczególności te ostatnie mają dużą wartość badawczą dla omawianych zgadanień. Nie bez znaczenia jest również fakt, że te czasy były bardzo burzliwe: od panowania Karola IV, poprzez walki między jego synami i pozostałymi członkami rodu Luksemburgów, na wojnach husyckich skończywszy.

Chronologia jest bardzo istotną kwestią. Logicznie rzecz biorąc, okres będący przedmiotem rozważań powinien się zacząć od panowania Jana Luksemburskiego, a więc od $1310 \mathrm{r}$. Jednak w tym momencie trudno mówić o Górnych Łużycach, a na dodatek omawiany obszar przez prawie cały czas jego rządów nie należał w pełni do wspomnianego króla. Dopiero pod koniec życia, w 1346 r., mógł się on tytułować władcą Łużyc. Wtedy też powstał Związek Sześciu Miast, który - jak już wcześniej zaznaczono - stał się zalążkiem powstania interesującego mnie regionu. Dlatego adekwatne dla moich dociekań będzie uznanie właśnie $1346 \mathrm{r}$. za początkową datę. Za koniec tego przedziału natomiast uważa się datę śmierci Zygmunta Luksemburczyka, czyli $1437 \mathrm{r}$.

$\mathrm{O}$ wiele trudniejsza do ustalenia jest terminologia dotycząca służby rycerskiej w odróżnieniu od mieszczańskiej. Druga z nich nie sprawia problemów, bowiem zasady powoływania sił zbrojnych w miastach nie były skomplikowane - podlegali im wszyscy mieszczanie zrzeszeni w cechach rzemieślniczych, względnie wszyscy podlegający prawu miejskiemu². Trudności nastręcza natomiast określenie pojęcia powinności wojskowych rycerstwa. Szlachta na Górnych Łużycach, w przeciwieństwie do Śląska czy sąsiednich Dolnych Łużyc, nie była liczna ${ }^{3}$, a zważywszy na silną przewagę Związku Sześciu Miast, traciła sporo ze swej siły na rzecz miast, a interesy obu tych stanów stały częstokroć w sprzeczności i przez to $\mathrm{w}$ wielu sytuacjach uniemożliwiały podjęcie jednogłośnej decyzji. Poza tym często zdarzało się, że w domyślnie pojmowanej powinności rycerskiej znajdowali się kopijnicy pochodzenia miejskiego, ponieważ ta kategoria posiadała ziemie, m.in. poprzez jej wykup od zubożałych szlachciców ${ }^{4}$. W związku z powyższym pod pojęciem „służba rycerska” rozumiem zobowiązania militarne pełnione na zasadzie powinności lennych, tzn. według posiadanych majątków ziemskich ${ }^{5}$.

\footnotetext{
2 Zob. M. Goliński, Uzbrojenie mieszczańskie na Śląsku od połowy XIV do końca XV w., „Studia i Materiały do Historii Wojskowości” (dalej: SMHW) 1990, s. 3.

F. Šmahel, Husitská revoluce, t. I, Praha 1995, s. 200-207.

4 Dzieje Górnych Łużyc..., s. 144-147.

Zob. prace M. Golińskiego: Służba rycerska a potencjat militarny księstw śląskich w późnym średniowieczu. I. Księstwo nysko-otmuchowskie, „Śląski Kwartalnik Historyczny Sobótka” (dalej:
} 
W kwestii używanych w niniejszym artykule terminów należy jeszcze wyjaśnić rozumienie uzbrojenia. Modyfikując definicję podaną przez Zdzisława Żygulskiego jr., mieszczą się w niej: broń zaczepna (biała, obuchowa itp.), ochronna (m.in. zbroje), a także artyleria (prochowa i machiny) ${ }^{6}$.

Ze względu na ubogą literaturę dotyczącą niniejszego tematu moja wypowiedź ma przede wszystkim charakter szkicu i jest formą zasygnalizowania istnienia problemu badawczego. $Z$ tego również powodu zdecydowałem się przedstawić poszczególne pozycje naukowe w porządku chronologicznym, a dla ukazania różnic w podejściu historyków polskich i niemieckich zostały te rozważania ujęte oddzielnie. Na tę chwilę praca może nie wyczerpywać tematu, dlatego wymagane będą dalsze studia. Przedstawiony przeze mnie stan badań pozwala jednak na ustalenie możliwych kierunków poszukiwań, które również zostaną ujęte w artykule.

\section{Materiał źródłowy}

Źródła, które mogłyby rzucić światło na interesujące mnie zagadnienie, są obfite. Najbardziej miarodajne występują w archiwach większości miast dawnego Związku Sześciu Miast. Spośród nich materiałów archiwalnych nie posiada jedynie Zittau (Żytawa), której najstarsze archiwalia pochodzą dopiero z 1757 r. - wcześniejsze uległy zniszczeniu podczas wojny siedmioletniej. Najbardziej wartościowe są rachunki miejskie znajdujące się w placówkach po niemieckiej stronie, zwłaszcza w Görlitz. W nieco mniejszym stopniu przydatne są natomiast kroniki miejskie, gdyż powstały w znacznej mierze $\mathrm{w}$ czasach nowożytnych, tylko nieliczne zostały napisane jeszcze u schyłku średniowiecza ${ }^{7}$. Materiały o charakterze prawnym, m.in. przywileje, wilkierze i inne zabytki miejskiego prawodawstwa, oprócz wspomnianych miast górnołużyckich, są zdeponowane także we Wrocławiu

„Sobótka”) 1998, nr 1-2, s. 33-65; Stużba rycerska a potencjał militarny księstw ślaskich w późnym średniowieczu. II. Księstwo wrocławskie na tle innych ziem dziedzicznych Korony czeskiej, „Sobótka” 1998, nr 3-4, s. 519-545; Stużba rycerska a potencjat militarny księstw śląskich w późnym średniowieczu. III. Uwagi ogólne, „Sobótka” 1999, nr 1, s. 1-17 oraz R. Heś, Uzbrojenie rycerskie na Śląsku w XIV wieku, Wrocław-Racibórz 2007, s. 3.

6 Z. Żygulski jr, Broń $w$ dawnej Polsce na tle uzbrojenia Europy i Bliskiego Wschodu, Warszawa 1982, s. 7. Cytowany autor w swoim przedmiocie zainteresowań, ze względów praktycznych, nie uwzględniał właśnie machin oblężniczych. $\mathrm{O}$ artylerii przedogniowej zob. T. Nowak, $Z$ dziejów techniki wojennej w dawnej Polsce, Warszawa 1965, s. 26-61 oraz J. Szymczak, Sprzęt i technika oblężnicza [w:] Polska technika wojskowa do 1500 roku, red. A. Nadolski, Warszawa 1994, s. 257-270.

7 Do naszych czasów zachowało się dużo kronik miast Górnych Łużyc, głównie Lubania, Zgorzelca i Budziszyna. Szczególnie dla tego ostatniego ośrodka miejskiego najliczniej występują zapiski kronikarskie i to tu właśnie znajdują się wzmiankowane średniowieczne źródła. 
(Archiwum Państwowe we Wrocławiu i Biblioteka Uniwersytecka we Wrocławiu $^{8}$ ), a także w Pradze (Národní archiv České republiky v Praze).

Spora część omawianego materiału źródłowego została już w XIX i na początku XX w. opracowana przez niemieckich historyków w formie katalogów i edycji źródłowych. Jedną z ważniejszych drukowanych pozycji są Scriptores rerum Lusaticarum, sporządzone na zlecenie Górnołużyckiego Towarzystwa Naukowego ${ }^{10}$. Na największą uwagę jednak zasługuje kodeks dyplomatyczny przygotowany przez Richarda Jechta, wybitnego zgorzeleckiego historyka i archiwistę $^{11}$. Choć w znacznej mierze skupił się na rachunkach miejskich Zgorzelca i ogólnie jego historii, to znakomicie przedstawił też źródła, które są bardzo istotne do poznania dziejów Górnych Łużyc w średniowieczu. W opinii historiografii ten zbiór materiałów uchodzi za najważniejszą pozycję w badaniach nad przeszłością kraju nad Nysą Łużycką ${ }^{12}$.

\section{Stan badań - strona niemiecka}

Okres oświecenia i założenie w 1779 r. Górnołużyckiego Towarzystwa Nauk (Oberlausitzische Gesellschaft der Wissenschaften) były zaczątkiem naukowego zainteresowania dziejami Górnych Łużyc. Efektem wczesnych poszukiwań stały się edycje źródeł i artykuły mające charakter przyczynkarski. Jednak głównymi problemami, z jakimi spotykała się działalność naukowa Towarzystwa, były toczące się w tym czasie wojny napoleońskie oraz

\footnotetext{
8 W Archiwum Państwowym we Wrocławiu znajdują się nowożytne odpisy aktów prawnych zgromadzonych w zbiorze Archiwum Stanów Krajowych Górnych Łużyc, zaś Dział Rękopisów Biblioteki Uniwersyteckiej posiada materiały pochodzące z dawnej Kolekcji Milicha oraz akcesje. Te ostatnie mają charakter kronikarski oraz katalogów. Dokumenty z pierwszej z wymienionych placówek oraz ze zbiorów zabezpieczonych Biblioteki są zinwentaryzowane i skatalogowane, natomiast wspomniana kolekcja została opracowana w postaci publikacji Katalog rękopisów obejmujący sygnatury 6268-6790: rękopisy nowożytne. Dawny zbiór Biblioteki J. G. Milicha w Zgorzelcu, oprac. L. Górecki, cz. 2, Wrocław 1990.

$9 \quad$ L. Matušiková, Prameny $k$ dějinám Horní Lužice ve fondech Státniho ústředního archivu $v$ Praze, „Mitteilungen des Zittauer Geschichts- und Museumsverein” (dalej: MZGM) 1997, s. 166-172. Obecna nazwa wspomnianego archiwum funkcjonuje od $2004 \mathrm{r}$.

10 Scriptores rerum Lusaticarum, wyd. przez Oberlausitzischen Gesellschaft der Wissenschaften, t. 1, Görlitz 1839. Na ten tom składają się kroniki i roczniki spisane przez autorów pochodzących z Łużyc (m.in. Jan z Gubina i franciszkanów ze Zgorzelca) oraz Śląska (Marcin z Bolkowa).
}

11 Dla interesującego mnie czasu opracował dwie edycje: Codex diplomaticus Lusatiae superioris II, wyd. przez R. Jechta, t. I-II, Görlitz 1896-1903 oraz Codex diplomaticus Lusatiae superioris III, wyd. przez R. Jechta, Görlitz 1905-1910. Pierwsza z nich obejmuje lata 14191437 (są to dwa tomy o ciągłej paginacji, z których pierwszy zawiera źródła z lat 1419-1428, a drugi $z$ lat 1429-1437), druga natomiast najstarsze rachunki z okresu 1337-1419.

12 J. Bahlcke, Górne Łużyce..., s. 52. 
powstały po kongresie wiedeńskim podział regionu na część saską i pruską, co w pewnym stopniu wpływało na jakość studiów ${ }^{13}$. Z pierwszej połowy XIX stulecia nie dysponujemy wieloma pozycjami omawiającymi zagadnienia służby mieszczańskiej i rycerskiej, nie mówiąc już o uzbrojeniu. $\mathrm{Na}$ uwagę zasługuje jednak praca Johanna Gotfreda Müllera o prawnych instytucjach feudalnych Górnych Łużyc ${ }^{14}$. Ta publikacja, napisana w języku łacińskim, omawia szczegółowo działania wspomnianych organów władzy oraz ich historyczne uwarunkowania. Osobny rozdział jest poświęcony powinnościom wojskowym ${ }^{15}$. Mimo ogólnego charakteru dzieła - bowiem tylko pobieżnie Müller opisał poszczególne epizody z dziejów regionu - uchodzi za najdokładniejsze kompendium wiedzy na temat interesującej mnie problematyki. Jest też wiarygodny, ponieważ pokrywa się w znacznym stopniu $\mathrm{z}$ wypowiedziami późniejszych badaczy ${ }^{16}$.

Bardziej wyczerpujące studia dotyczące omawianego zagadnienia pojawiają się dopiero w drugiej połowie XIX w. ${ }^{17}$, zwłaszcza po zjednoczeniu Niemiec. Stało się to za sprawą dwóch wybitnych niemieckich historyków regionu: Hermanna Knothego i Richarda. Ich rzetelne badania okazały się podstawą dla następnych pokoleń historyków podejmujących podobną tematykę i nawet dzisiaj, pomimo upływu czasu, uchodzą za aktualne pozycje. Poniżej zostaną omówione najważniejsze ich prace - cenne z punktu widzenia badacza zajmującego się problemem służby wojskowej w późnym średniowieczu.

Knothe w 1879 r. napisał rozprawę poświęconą historii szlachty górnołużyckiej i jej dóbr w okresie od XIII stulecia do $1620 \mathrm{r}^{18}{ }^{18}$, opartą na solidnej bazie źródłowej. Swoje rozważania podzielił na trzy główne części: historię szlachty, spis ich przedstawicieli oraz dóbr. Pierwsza z nich praktycznie

13 Ibidem, s. 33-48.

14 J.G. Müller, Institutiones juris feudalis Lusatiae Superioris, t. 1, Lipsiae 1818.

15 Ibidem, s. 367-400.

16 Zob. np.: P. Contamine, Wojna w średniowieczu, tłum. M. Czajka, Warszawa 1999, s. 8586, 130-131, 161-183 oraz K. Orzechowski, Historia ustroju Śląska 1202-1740, Wrocław 2005, s. 81-84. Warta uwagi jest również praca U. Trespa, Söldner aus Böhmen: im Dienst deutschen Fürsten; Kriegsgeschäft und Heeresorganisation in 15. Jahrhundert, Paderborn 2004.

17 Pierwsze artykuły poruszające pośrednio interesujący mnie temat pojawiają się od 1860 r.: J. G. Kloss, Historische Nachricht von dem Hussitenkriege in der Oberlausitz seit dem Jahre 1430, „Neues Lausitzisches Magazin” (dalej: NLM) 1860, s. 1-34. Następne ukazują się w 1868 r.; H. Knothe, Das ritterliche Geschlecht der Schaff im Meißnischen und in der Oberlausitz, NLM 1868, s. 19-26 oraz G. Korschelt, Kriegsdrangsale der Oberlausitz zur Zeit des Hussitenkrieges, NLM 1868, s. 173-186, a od lat osiemdziesiątych XIX w. wypowiadają się historycy regularnie na łamach cytowanego czasopisma. Na uwagę zasługują m.in.: H. Knothe, Geschichte der Oberlausitz unter dem Landvogte Hinko Hlawatsch von der Duba 1410 bis 1420, NLM 1890, s. 74-113 oraz idem, Die ältesten Siegel der Oberlausitzischen Adels, NLM 1891, s. 1-32.

18 H. Knothe, Geschichte des Oberlausitzer Adels und seiner Güter, Leipzig 1879. 
ujawnia jego zainteresowania badawcze Górnymi Łużycami i historią regionu, w tym przede wszystkim społeczną ${ }^{19}$, bowiem początkowy rozdział obejmuje m.in. zagadnienia onomastyczne, np. pochodzenie nazw rodów, chociaż ogólnie jest mowa o pochodzeniu szlachty Górnych Łużyc. Dalej znajdujemy fragmenty poświęcone zróżnicowaniu społecznemu i relacjom rycerstwa z władcami, Kościołem oraz miastami. Osobno zostały potraktowane zagadnienia dotyczące kultury omawianego stanu, ale z punktu widzenia historyka zajmującego się poruszanym problemem jest on istotny, ponieważ zawiera nieduży - bowiem liczący jedynie 5 stron - podrozdział dotyczący sił zbrojnych i uzbrojenia ${ }^{20}$. Niestety jest on napisany bardzo ogólnie i ma mało odnośników do innych źródeł i opracowań, co jednak jest do usprawiedliwienia, bowiem samo zagadnienie w momencie wydania rozprawy było słabo rozpoznane, a poza tym dzieło ma charakter syntetyczny i ze względów praktycznych nie mogło być szczegółowo rozwinięte. Najistotniejsze jednak dla mnie jest przede wszystkim to, jak wyglądała - oczywiście w ogólnym zarysie - ewolucja uzbrojenia rycerskiego, służba wojskowa oraz udział rycerzy górnołużyckich w turniejach.

Następne dwie części opisują rody szlacheckie znajdujące się na terytorium Związku Sześciu Miast oraz ich dobra. Właściwie można powiedzieć, że są to katalogi, ponieważ zwięźle omawiają poszczególne rodziny wraz $\mathrm{z}$ ich bocznymi liniami oraz dokonaniami ${ }^{21}$. Podobnie również wygląda fragment poświęcony posiadłościom ziemskim, przy czym występuje podział na „władztwa wielkie” (die grossen Herrschaften) ${ }^{22}$ i „okręgi miejskie” (die Weichbilde der Städte) ${ }^{23}$. Omawiane partie pracy zawierają dokładne informacje, na podstawie których można wyciągnąć równie konkretne wnioski co do powinności wojskowych szlachty. Dodatkowym atutem dzieła Knothego jest to, że koncentruje się głównie na faktografii i jednocześnie nie wygłasza poglądów wartościujących, co w warunkach XIX stulecia jest nieczęsto spotykane. Tytułem podsumowania można powiedzieć, że omawiana rozprawa jest rzetelnym studium historii społecznej i regionu, opartym na solidnej bazie źródłowej. Choć kwestie wojskowe nie są szeroko rozpatrywane, to badacz zajmujący się służbą rycerską powinien te zagadnienia wziąć pod uwagę, gdyż zawarte rozważania pozwalają na zrozumienie sytuacji ekonomicznej i społecznej szlachty.

\footnotetext{
19 Zob. J. Bahlcke, Górne Łużyce..., s. 49-50.

20 H. Knothe, Geschichte des Oberlausitzer..., s. 95-100.

21 Ibidem, s. 106-543.

22 Ibidem, s. 548.

23 Ibidem, s. 551. Liczba mnoga w Nominativie das Weichbild to die Weichblider, jednak zdecydowałem się zachować formę Weichbilde, gdyż taka właśnie występuje w omawianym dziele. Jest to archaizm językowy, jaki często można zauważyć w tej pracy.
} 
Niezaprzeczalnie najbardziej wartościowymi pracami są efekty badań wspomnianego już wcześniej Jechta. Przede wszystkim należy wskazać jego pracę o wojnach husyckich na Górnych Łużycach i panowaniu Zygmunta Luksemburczyka w tym regionie ${ }^{24}$. Podobnie jak rozprawa Knothego, również jest oparta na solidnej bazie źródłowej, jednak jest to bardziej widoczne w postaci licznych odsyłaczy, przede wszystkim do - opracowanego zresztą przez niego samego - Codex diplomaticus Lusatiae Superioris. Oprócz przywołanego zbioru dokumentów wykorzystał także materiały pochodzące $\mathrm{z}$ archiwów górnołużyckich oraz, w niewielkim stopniu, dorobku czeskiej historiografii - głównie kronikę Bartoška z Drahonic ${ }^{25}$ oraz pracę Františka Palackiego ${ }^{26}$.

Niejednokrotnie autor daje upust swoim poglądom politycznym i narodowościowym, nie wpływają one jednak znacząco na jakość studium, a jest wręcz przeciwnie - są to rzetelne rozważania. Do dzisiaj stanowią podstawę do badań nad późnośredniowiecznymi dziejami Górnych Łużyc. W pierwszej chwili czytelnik dostrzeże, że omawiana rozprawa jest zarysem dziejów, poddanym wnikliwej analizie i krytyce. Uważna lektura przedstawi jednak nieco odmienny obraz. Na początku autor omawia sytuację panującą nad górnym biegiem Nysy Łużyckiej przed rewolucją husycką, zestawioną $\mathrm{w}$ niewielkim stopniu z równoległymi wydarzeniami w Czechach. Choć nie ma typowego podziału na rozdziały, a jedynie lata są takimi wyznacznikami, to można dostrzec pewnego rodzaju uporządkowanie. Na wstępie każdego $\mathrm{z}$ omawianych lat krótko zarysowano sytuacja panująca $\mathrm{w}$ danym roku, a dalej już szczegółowo przedstawiono wydarzenia polityczne, militarne, społeczne oraz dzieje Zgorzelca. Szczególnie te ostatnie zagadnienia były przez Jechta często poruszane, co jest typowe dla jego prac. Było to spowodowane nie tylko uwarunkowaniami dziejowymi, ale także swoistym patriotyzmem lokalnym niemieckiego historyka, choć z drugiej strony jest to do usprawiedliwienia z jeszcze jednego powodu - zgorzeleckie archiwa są najbogatsze ze wszystkich górnołużyckich miast. Dzięki jego dogłębnemu spojrzeniu możemy też poznać rozmiar i wymiar służby mieszczan i rycerstwa oraz uzbrojenie $\mathrm{z}$ tamtego okresu.

24 R. Jecht, Der Oberlausitzer Hussitenkrieg und das Land der Sechsstädte unter Kaiser Sigmund, t. 1-2, Görlitz 1911. Oba tomy cytowanego dzieła mają ciągłą paginację. W streszczonej formie: idem, Geschichte der Stadt Görlitz, t. 1, Görlitz 1926, s. 149-165.

25 Idem, Der Oberlausitzer Hussitenkrieg..., t. 1, s. 226. W tym konkretnym przypadku powołał się na edycję znajdującą się w Monumenta Historica Bohemiae, t. 1, Pragae 1754, s. 143-218. Jecht mógł znać też późniejszą wersję w Fontes rerum Bohemicarum, oprac. J. Goll, t. 5, Praha 1893, s. 589-628.

26 F. Palacký, Geschichte von Böhmen, t. 4, Prag 1857. 
Powyższe zagadnienia zostały przedstawione niemal $\mathrm{z}$ aptekarską precyzją, bowiem znajdują się w nich konkretne liczby i fakty, choć w kilku miejscach dysertacji Jechta natrafić można na merytoryczne - z perspektywy dzisiejszej historiografii - błędy, jednakże są one do wybaczenia, ponieważ w czasach współczesnych publikacji takie poglądy były aktualne. Chodzi m.in. o podawane liczebności jednostek wystawianych przez Zgorzelec, zwłaszcza jeśli mowa o kopiach, gdzie autor skład tej jednostki taktycznej ustalił na czterech jeźdźców ${ }^{27}$. Takie pomyłki są jednak rzadkie, a wynikają one głównie z powszechnej niedokładności źródeł w kwestii liczby wojsk.

Choć powyższe studia obejmują jedynie lata 1419-1437, a więc zaledwie niewielką część interesującego mnie przedziału, to w tym względzie Jecht poświęcił wcześniejszym okresom jeszcze kilka rozpraw. Jedną z nich jest spisana przez niego monografia dziejów Zgorzelca. Choć i tu wyraźnie widać jego mocne zamiłowanie do miasta nad Nysą Łużycką, historyk zajmujący się omawianym tematem znajdzie tam bogate zestawienia liczb i informacji źródłowych, opatrzonych licznymi odsyłaczami i komentarzami. Ogólnie można powiedzieć, że badania zgorzeleckiego historyka stały się i są nadal podstawą do badań nad wojskowością Górnych Łużyc w późnym średniowieczu, o czym świadczą liczne cytowania zarówno przez niemieckich, jak i polskich badaczy.

W pierwszej połowie XX w., a zwłaszcza w latach międzywojennych, coraz częściej zaczęły się pojawiać publikacje traktujące o wojskowości Górnych Łużyc, choć nie można tu mówić oczywiście o prężnym rozwoju badań w tym kierunku. Niemniej jednak postęp w tej dziedzinie jest zauważalny. Taki stan rzeczy jest wynikiem nie tylko rozwoju studiów nad sztuką wojenną w średniowieczu, ale po części również sytuacji panującej w Niemczech po I wojnie światowej, na które przecież nałożono ogromne sankcje i kontrybucje.

W 1927 r. Walter von Boetticher opublikował swoją pracę na temat szlachty z okręgu zgorzeleckiego na przełomie XIV i XV stulecia ${ }^{28}$. Wspomniany historyk, pochodzenia inflanckiego (z Rygi), w swoim dorobku miał przede wszystkim rozprawy dotyczące dziejów szlachty górnołużyckiej i w nieco mniejszym stopniu regionu ${ }^{29}$. Zasadniczo jest to katalog zawierający spis rodów funkcjonujących w okolicy Zgorzelca, który na pierwszy

27 R. Jecht, Der Oberlausitzer Hussitenkrieg..., t. 1, s. 23-24. Zob. uwagi M. Golińskiego, Służba rycerska a potencjał militarny księstw śląskich w późnym średniowieczu. III..., s. 1-17.

28 W. von Boetticher, Der Adel des Görlitzer Weichbildes um die Wende des 14. und 15. Jahrhunderts, Görlitz 1927.

29 Walter Boetticher - Biographisches Lexikon der Oberlausitz, https://web.archive.org/ web/20140826115851/http://wiki2.olgdw.de/index.php?title=Walter_Boetticher（dostęp 21 III 2018). 
rzut oka jest podobny do dzieła Knothego. Uważna analiza pokazuje jednak, że w stosunku do niego jest bardziej precyzyjny, zawiera dużo dokładnych informacji i liczb. Kolejną znaczącą różnicą jest położony większy nacisk na kwestie wojskowe - stosunek zgorzeleckiego rycerstwa do służby militarnej oraz jej wymiar, co widać nie tylko we wspomnianym zestawieniu, ale przede wszystkim we wprowadzeniu ${ }^{30}$.

Dwa lata po wydaniu przez von Boettichera katalogu szlachty Wilhelm Felix opublikował swoją pracę na temat sił zbrojnych Budziszyna w średniowieczu $^{31}$. Felix był nauczycielem, pedagogiem oraz - pod koniec życia - dyrektorem Pestalozzi-Schule w Budziszynie (Bautzen), jednej z nielicznych w okresie międzywojennym koedukacyjnych szkół. Przez dziewięć lat uczył też w Kapitulanten Schule des Infanterie- und Husarenregimentes Nr. 103 in Bautzen. W swoim dorobku naukowym poświęcał się dziejom Budziszyna, zwłaszcza militarnym ${ }^{32}$. Warto zwrócić uwagę na dwie istotne sprawy dotyczące omawianego dzieła. Pierwszą z nich jest przywoływana przez autora kwestia źródeł. Mianowicie wskazuje na dość poważne braki tych materiałów, zwłaszcza jeśli chodzi o okres XIII-XVII w., bowiem uległy one zniszczeniu podczas pożaru miasta $\mathrm{w} 1634 \mathrm{r}$., w związku z tym badacz był zmuszony korzystać $\mathrm{w}$ znacznej mierze z późniejszych źródeł oraz równoległych ze Zgorzelca, Wrocławia i Pragi ${ }^{33}$. Druga sprawa to problematyczna periodyzacja, gdyż mimo wyraźnie zaznaczonego w tytule średniowiecza można znaleźć liczne odwołania do czasów nowożytnych, co wywołuje u czytelnika niemałe zakłopotanie. Określenie ram chronologicznych i ich uzasadnienie powinno się znaleźć we wstępie, ale niestety z krótkiego wprowadzenia nie można się tego dowiedzieć ${ }^{34}$. O tym, co konkretnie niemiecki historyk miał na myśli, mówiąc o średniowiecznym wojsku, można się domyślić jedynie z bardzo wnikliwej analizy - mianowicie przez powyższy termin rozumiał siły zbrojne mobilizowane i zorganizowane na zasadach panujących w epoce średniowiecza. Nawet mimo to ramy czasowe tej epoki są bardzo ogólnie zarysowane - trudno jest ustalić początkową datę, natomiast można wywnioskować z wywodu autora koniec tego okresu - czasy wojny trzydziestoletniej ${ }^{35}$. Nieco lepiej wyjaśnione są zasady organizacji militarnej, m.in. przynależność do prawa miejskiego, podział na dzielnice oraz powinności lenne wasali.

\footnotetext{
30 W. von Boetticher, Der Adel..., s. 1-19.

31 W. Felix, Bautzens wehrhafte Bürgerschaft in Mittelalter, Bautzen 1929.

32 Felix Wilhelm, http://www.wilhelm-bautzen.de/personen/felix/index.html (dostęp 30 III 2018).

33 W. Felix, Bautzens wehrhafte..., s. 3.

34 Ibidem, s. 3.

35 Ibidem, s. 9.
} 
Ogólnie o dziele Felixa można powiedzieć, że jest to próba rekonstrukcji sił zbrojnych miasta nad Sprewą i to dość mocna, jeśli weźmiemy pod uwagę wspomniane przeze mnie problemy. Dość często autor powołuje się na analogie z innych ośrodków górnołużyckich czy późniejszych epok, co jest praktyką dość często stosowaną przez historyków, zwłaszcza tych zajmujących się erą przedindustrialną, choć jest to również dość ryzykowna i niemiarodajna metoda. Badacz podzielił swoje rozważania na kilka zagadnień: skład sił zbrojnych, ich struktury, chorągwi, broni, ćwiczeń wojskowych, artylerii ${ }^{36}$, miejskich żołnierzy, działań obronnych mieszczan, wewnętrznych niepokojów, zewnętrznych zobowiązań, wypraw wojennych, funkcjonowaniu w Związku Sześciu Miast oraz strat wojska. W wypowiedziach Felixa można wyczuć typowe dla niemieckiej historii regionalnej umiłowanie w pierwszej kolejności do lokalnej ojczyzny, która jest częstokroć idealizowana, tak samo jak jej mieszkańcy. $Z$ drugiej strony stara się zachować rzetelność swoich badań. Generalnie można powiedzieć, że z perspektywy historyka zajmującego się tematem sił zbrojnych Górnych Łużyc omawiana rozprawa jest warta uwagi, chociaż należy ją traktować z przymrużeniem oka, bowiem - jak zaznaczyłem wcześniej - jest oparta na nie do końca wiarygodnej metodologii.

Od zakończenia II wojny światowej nie znajduję żadnej pozycji traktującej o służbie wojskowej rycerstwa i mieszczan oraz uzbrojenia za czasów luksemburskich ${ }^{37}$. Na Górnych Łużycach po niemieckiej stronie w dalszym ciągu są prowadzone badania nad ich dziejami, jednak obejmują one głównie historię społeczną, gospodarczą oraz poszczególnych miejscowości. Historia wojskowości nie zajmuje poczesnego miejsca w zainteresowaniach badawczych niemieckich historyków. Taka sytuacja występuje z wielu powodów. Przypuszczalnie jest to wynik pacyfistycznych nastrojów panujących $\mathrm{w}$ społeczeństwie niemieckim oraz powszechnego przekonania, że wszystko, co wiemy na temat regionu nad Nysą Łużycką, zostało już powiedziane przez XIX i XX-wiecznych badaczy.

\section{Stan badań - strona polska}

Stan badań po polskiej stronie jest dużo uboższy w stosunku do niemieckiej historiografii. Oczywiście ma to związek z tym, że wschodnia część

\footnotetext{
36 Rozdział oryginalnie nazywa się „Die Geschütze”, co można tłumaczyć dosłownie jako „działa”, ale ponieważ autor omawia także machiny oblężnicze nieużywające prochu, zdecydowałem się na użycie określenia „artyleria” (ibidem, s. 12).

37 Zob. aneks w katalogu Adel in Schlesien und in der Oberlausitz: Mittelalter, Neuzeit, Gegenwart. Szlachta na Śląsu i Górnych Łużycach: średniowiecze, nowożytność, współczesność, b.m.w. 2014, s. 328-337.
} 
Górnych Łużyc należy do naszego państwa od zaledwie 74 lat, a przynależność omawianego regionu do ziem polskich (czy też śląskich) w przeszłości była krótkotrwała i zdecydowanie nie mieściła się w dzisiejszych pojęciach przynależności terytorialnej i państwowej. Innym powodem takiego stanu rzeczy jest fakt, że historia regionalna - $\mathrm{w}$ przeciwieństwie do Niemiec - nie ma mocno ugruntowanej tradycji w Polsce. Jednym z takich przykładów są studia nad dziejami Śląska do dziś prowadzone w największym stopniu przez wrocławskie środowisko historyków. W tym przypadku tu właśnie pojawiały się nieliczne wzmianki o Górnych Łużycach w późnym średniowieczu, jednak znajdowały się przeważnie na marginesie rozważań, jako dygresja. Dopiero od upadku ustroju komunistycznego w 1989 r. można zaobserwować poważniejsze zainteresowania regionem nad prawym brzegiem Nysy Łużyckiej.

Po raz pierwszy ziemie te $\mathrm{w}$ interesującym mnie okresie pojawiają się $\mathrm{w}$ polskim dyskursie historycznym pod koniec lat osiemdziesiątych XX $\mathrm{w}$. za sprawą Mateusza Golińskiego, wybitnego wrocławskiego mediewisty. W swoich rozważaniach na temat broni palnej na Śląsku do lat trzydziestych XV w. ujął oblężenia Lubania z lat 1427 i 1431, które jednak znalazły się mimo wszystko na marginesie jego wypowiedzi ${ }^{38}$. Choć ten historyk przede wszystkim chciał ukazać zastosowanie broni prochowej, to jednocześnie poddał krytyce opis wydarzeń przedstawiony przez Jechta ${ }^{39}$. Generalnie jego interpretacja nie budzi zastrzeżeń, jednak - podobnie jak zresztą wielu historyków ${ }^{40}$ - uległ po części romantycznej wizji sabotażu przez husytów Baszty Brackiej podczas szturmu w $1431 \mathrm{r}^{41} \mathrm{Na}$ jego usprawiedliwienie można dodać, że wrocławski mediewista nie prowadził badań nad dziejami regionu nad Nysą Łużycką.

W 1997 r., z okazji przypadającej w 1996 r. 650 rocznicy utworzenia Związku Sześciu Miast, niemieckie czasopismo naukowe "Mitteilungen des Zittauer Geschichts- und Museumsvereins" opublikowało specjalne wydanie, w którym wypowiadali się przedstawiciele Historycznej Komisji

38 M. Goliński, Broń palna na Śląsku do lat trzydziestych XV w. oraz jej zastosowanie przy obronie i zdobywaniu twierdz, SMHW 1988, s. 21-23. Należy jednak jego wywody w ogóle na temat broni palnej uznać za adekwatne w stosunku do warunków panujących na Górnych Łużycach.

39 R. Jecht, Der Oberlausitzer Hussitenkrieg..., t. 1-2, s. 132-136; 289-295.

40 Np. J. Durdik, Sztuka wojenna husytów, tłum. J. Chlabicz, Warszawa 1955, s. 175-176.

41 Kwestia ataku na wieżę obecnie budzi zastrzeżenia. U Marcina z Bolkowa znajdujemy taką wzmiankę: „Alleyne das dy hussen den Sittischen torm vndirgruben vnde durchhagten vnde trugen doreyn vil fas vnde czundten dy fas an", Scriptores rerum Lusticiarum..., s. 367. Ogólnie ze wskazanego opisu nie wynika, która to była wieża, co stało się powodem do snucia domysłów przez nowożytnych kronikarzy. Nawiasem mówiąc, dyskutowaliśmy na ten temat $\mathrm{z}$ dr. Łukaszem Tekielą, któremu pragnę serdecznie podziękować za uwagi. 
Euroregionu Nysa (Geschichtsskommission der Euroregion Neiße) z Polski, Czech i Niemiec. W tym tomie znajduje się artykuł Stanisława Firszta, reprezentującego jeleniogórskie środowisko historyczne, traktujący o uzbrojeniu wojsk miejskich w tej części Europy ${ }^{42}$. W swojej wypowiedzi opierał się głównie na dokonaniach polskich historyków, natomiast w bardzo małym stopniu wykorzystał niemieckie studia dotyczące Śląska ${ }^{43}$. Archeolog z Jeleniej Góry skupił się nie tylko na samym uzbrojeniu, ale również na funkcjonowaniu milicji miejskiej w wiekach średnich zarówno w społeczeństwie, jak i w podmiotach politycznych, wszystko to jednak zostało opisane w dość ogólnej formie, a o Związku Sześciu Miast wypowiedział się zaledwie w kilku zdaniach ${ }^{44}$. Pomimo tak zdawkowego omówienia zagadnienia nie można odmówić tej pracy waloru poznawczego, dzięki któremu można sobie wyobrazić wygląd i działalność wojsk górnołużyckich w późnym średniowieczu.

Zgoła odmienny obraz wojskowości Górnych Łużyc pozostawił Robert Heś, znakomity badacz dziejów średniowiecznego Śląska związany z Muzeum Narodowym we Wrocławiu. W swoim dorobku naukowym ma też studia poświęcone Zgorzelcowi, $\mathrm{w}$ tym o broni palnej w tym mieście na przełomie XIV i XV w., które zostaną pokrótce omówione ${ }^{45}$. W swoim dziele opierał się na dorobku niemieckich badaczy regionu z Jechtem na czele i zestawiał to $\mathrm{z}$ dokonaniami polskich historyków. Omówione zostały liczne zagadnienia związane ze zgorzelecką artylerią prochową z ogromną precyzją i sprawnością, co czyni zeń wartościową pozycję naukową. Autor zaznaczył na końcu, że jego wypowiedź jest jedynie wstępem do badań nad tym rodzajem uzbrojenia $w$ nadnyskim mieście ${ }^{46}$, niemniej jednak jest to bardzo dobry początek, tym bardziej że - jak zaznaczyłem wcześniej - nawet w niemieckiej historiografii nie dysponujemy zbyt wieloma opracowaniami dotyczącymi wojskowości Górnych Łużyc XIV i XV stulecia.

42 S. Firszt, Uzbrojenie oddziałów miejskich w Środkowej Europie w okresie średniowiecza, MZGM 1997, s. 28-36.

43 Przede wszystkim wykorzystany został Codex diplomaticus Silesiae, wyd. przez G. Croona, Breslau 1912 oraz kilka monograficznych prac dotyczących Legnicy. Autor uwzględnił także przetłumaczone na język polski dzieło P. Berkela, Historia miasta Lubań, tłum. S. Tymicz, Wrocław 1992. Ostatnia z wymienionych pozycji, mimo dość dobrego przekładu, jest jednak obarczona błędami, wynikającymi z nieznajomości terminologii ustrojowej.

44 S. Firszt, Uzbrojenie oddziałów..., s. 35.

45 R. Heś, Początki broni palnej w Zgorzelcu (Görlitz) 1393-1420, „Acta Militaria Mediaevalia” 2009, s. 137-145. Znajomość dorobku górnołużyckich badaczy wykazał cytowany autor również we wcześniejszej pracy o uzbrojeniu śląskiego rycerstwa w XIV stuleciu (zob. idem, Uzbrojenie rycerskie..., s. 147-159).

$46 \quad$ Idem, Poczatki broni palnej..., s. 144. 


\section{Zakończenie}

Stan badań nad dziejami wojskowości Górnych Łużyc w XIV i XV w. jest dość skromny. Przyczyn takiej sytuacji należy dopatrywać się w stosunkowo słabym zainteresowaniu tematem. Trudno natomiast obarczać winą za ten stan rzeczy dobrze zachowany materiał źródłowy, nawet pomimo sporych braków dla okresu późnego średniowiecza. Natomiast dzieła pochodzące z czasów nowożytnych mają dużą wartość, ponieważ opierają się na dzisiaj zaginionych zasobach i z tego powodu są niekiedy jedynymi źródłami informacji.

Ogromne różnice widoczne są także w przypadku studiów dokonanych przez niemiecką i polską historiografię. Największy dorobek w tym względzie mają oczywiście ci pierwsi, ponieważ mieli niemal nieograniczony dostęp do archiwów i bibliotek. Nie mniej ważnym czynnikiem było też to, że spora część historyków pochodziła $\mathrm{z}$ tamtych terenów i częstokroć tworzyli z zamiłowania do regionu, a czasem również z poczucia odrębności krainy w przeszłości, co jest szczególnie widoczne w przypadku Jechta. Z kolei w naszym kraju problem ten jest bardzo słabo znany, nawet same Górne Łużyce nie są naukowo zbadane w dostatecznym stopniu. Taki stan rzeczy wynika przede wszystkim z krótkotrwałej przynależności regionu do Polski i dość słabego powiązania historycznego $\mathrm{z}$ państwem. Choć $\mathrm{w}$ nauce dostrzegano odrębność Łużyc, to władze polskie częstokroć próbowały „połączyć" je ze Śląskiem i traktowano je jako Ziemie Odzyskane, co zresztą jest do dzisiaj widoczne: stacja kolejowa w Lubaniu w nazwie posiada przymiotnik „śląski”, a w herbie polskiego Zgorzelca występuje śląski orzeł ${ }^{47}$. Tematyka łużycka tonęła w dyskursie nad historią Śląska. Dopiero od transformacji ustrojowej w 1989 r. można zaobserwować spore zainteresowanie krajem nad Nysą Łużycką. Nie jest to wprawdzie jeszcze zadowalający stan, jednak wygląda to obiecująco.

Na podstawie przedstawionego przeze mnie stanu badań uważam, że zagadnienie służby rycerskiej i mieszczańskiej oraz jej uzbrojenia na Górnych Łużycach wymaga stworzenia całościowego studium. Potrzeba ta jest podyktowana chociażby faktem rosnącego zainteresowania omawianym regionem, a inspiracją w tym względzie, także i dla mnie, są studia dotyczące wojskowości Śląska w późnym średniowieczu dokonane w największym stopniu przez Golińskiego i Hesia. Ewentualna taka praca będzie przede wszystkim rekonstrukcją służby oraz rynsztunku, choć nie mniej istotne będą zagadnienia pośrednio związane $\mathrm{z}$ omawianym tematem. W pierwszym przypadku będzie to przedstawienie rozmiaru i wymiaru powinności wojskowych i organizacji oraz na ich podstawie ustalenie siły militarnej

47 Do stworzenia godła miasta posłużył herb sprzed 1433 r., w którym występował czeski lew. 
Związku Sześciu Miast w późnym średniowieczu. Druga kwestia to będzie przeanalizowanie ewolucji rozwoju oręża $\mathrm{w}$ regionie na przestrzeni lat $1346-1437^{48}$. Dla zbudowania pełnego obrazu i zrozumienia opisywanego stanu rzeczy niezbędne będzie skrótowe omówienie sytuacji politycznej, społecznej i ekonomicznej panującej na Górnych Łużycach.

\section{Bibliografia}

\section{Źródła drukowane}

Codex diplomaticus Lusatiae superioris II, wyd. przez R. Jechta, t. I-II, Görlitz 18961903.

Codex diplomaticus Lusatiae superioris III, wyd. przez R. Jechta, Görlitz 1905-1910.

Codex diplomaticus Silesiae, wyd. przez G. Croona, Breslau 1912.

Fontes rerum Bohemicarum, wyd. przez J. Golla, t. 5, Praha 1893.

Monumenta Historica Bohemiae, t. 1, Pragae 1754.

Scriptores rerum Lusaticarum, red. Oberlausitzischen Gesellschaft der Wissenschaften, t. 1, Görlitz 1839.

\section{Opracowania}

Adel in Schlesien und in der Oberlausitz: Mittelalter, Neuzeit, Gegenwart. Szlachta na Śląsku i Górnych Łużycach: średniowiecze, nowożytność, współczesność, b.m.w. 2014.

Berkel P., Historia miasta Lubań, tłum. S. Tymicz, Wrocław 1992.

Boetticher W. von, Der Adel des Görlitzer Weichbildes um die Wende des 14. und 15. Jahrhunderts, Görlitz 1927.

Contamine P., Wojna w średniowieczu, tłum. M. Czajka, Warszawa 1999.

Durdik J., Sztuka wojenna husytów, tłum. J. Chlabicz, Warszawa 1955.

Dzieje Górnych Łużyc. Władza, społeczeństwo i kultura od średniowiecza do końca XX wieku, red. J. Bahlcke, tłum. M. Słoń, Warszawa 2007.

Felix W., Bautzens wehrhafte Bürgerschaft in Mittelalter, Bautzen 1929.

Firszt S., Uzbrojenie oddziałów miejskich w Środkowej Europie w okresie średniowiecza, „Mitteilungen des Zittauer Geschichts- und Museumsverein” 1997, s. 28-36.

Goliński M., Broń palna na Śląsku do lat trzydziestych XV w. oraz jej zastosowanie przy obronie i zdobywaniu twierdz, „Studia i Materiały do Historii Wojskowości” 1988, s. 3-26.

Goliński M., Uzbrojenie mieszczańskie na Ślasku od połowy XIV do końca XV w., „Studia i Materiały do Historii Wojskowości” 1990, s. 3-26.

Goliński M., Stużba rycerska a potencjał militarny księstw ślaskich w późnym średniowieczu. I. Księstwo nysko-otmuchowskie, „Śląski Kwartalnik Historyczny Sobótka” 1998, nr 1-2, s. 33-65.

48 Zob. R. Heś, Uzbrojenie rycerskie..., s. 10. 
Goliński M., Stużba rycerska a potencjał militarny księstw ślaskich w późnym średniowieczu. II. Księstwo wrocławskie na tle innych ziem dziedzicznych Korony czeskiej, „Sobótka” 1998, nr 3-4, s. 519-545.

Goliński M., Służba rycerska a potencjał militarny księstw śląskich w późnym średniowieczu. III. Uwagi ogólne, „Sobótka” 1999, nr 1, s. 1-17.

Heś R., Uzbrojenie rycerskie na Śląsku w XIV wieku, Wrocław-Racibórz 2007.

Heś R., Początki broni palnej w Zgorzelcu (Görlitz) 1393-1420, „Acta Militaria Mediaevalia" 2009, s. 137-145.

Jecht R., Der Oberlausitzer Hussitenkrieg und das Land der Sechsstädte unter Kaiser Sigmund, t. 1-2, Görlitz 1911.

Jecht R., Geschichte der Stadt Görlitz, t. 1, Görlitz 1926.

Katalog rękopisów obejmujący sygnatury 6268-6790: rękopisy nowożytne. Dawny zbiór Biblioteki J. G. Milicha w Zgorzelcu, oprac. L. Górecki, cz. 2, Wrocław 1990.

Kloss J. G., Historische Nachricht von dem Hussitenkriege in der Oberlausitz seit dem Jahre 1430, „Neues Lausitzisches Magazin” 1860, s. 1-34.

Knothe H., Das ritterliche Geschlecht der Schaff im Meißnischen und in der Oberlausitz, NLM 1868, s. 19-26.

Knothe H., Geschichte des Oberlausitzer Adels und seiner Güter, Leipzig 1879.

Knothe H., Geschichte der Oberlausitz unter dem Landvogte Hinko Hlawatsch von der Duba 1410 bis 1420, „Neues Lausitzisches Magazin” 1890, s. 74-113.

Knothe H., Die ältesten Siegel der Oberlausitzischen Adels, „Neues Lausitzisches Magazin" 1891, s. 1-32.

Korschelt G., Kriegsdrangsale der Oberlausitz zur Zeit des Hussitenkrieges, „Neues Lausitzisches Magazin” 1868, s. 173-186.

Matušiková L., Prameny k dějinám Horní Lužice ve fondech Státniho ústředního archivu v Praze, „Mitteilungen des Zittauer Geschichts- und Museumsverein” 1997, s. $166-172$.

Müller J. G., Institutiones juris feudalis Lusatiae Superioris, t. 1, Lipsiae 1818.

Nowak T., Z dziejów techniki wojennej w dawnej Polsce, Warszawa 1965.

Orzechowski K., Historia ustroju Śląska 1202-1740, Wrocław 2005.

Palacký F., Geschichte von Böhmen, t. 4, Prag 1857.

Šmahel F., Husitská revoluce, t. I, Praha 1995.

Szymczak J., Sprzęt i technika oblężnicza [w:] Polska technika wojskowa do 1500 roku, red. A. Nadolski, Warszawa 1994, s. 257-270.

Tresp U., Söldner aus Böhmen: im Dienst deutschen Fürsten; Kriegsgeschäft und Heeresorganisation in 15. Jahrhundert, Paderborn 2004.

Żygulski Z. jr, Broń w dawnej Polsce na tle uzbrojenia Europy i Bliskiego Wschodu, Warszawa 1982.

\section{Internet}

Felix Wilhelm, http://www.wilhelm-bautzen.de/personen/felix/index.html (dostęp 30 III 2018).

Walter Boetticher - Biographisches Lexikon der Oberlausitz, https://web.archive.org/ web/20140826115851/http://wiki2.olgdw.de/index.php?title=Walter_Boetticher (dostęp 21 III 2018). 


\title{
STRESZCZENIE
}

\author{
Michał Dudziński, Służba rycerska i mieszczańska oraz jej \\ uzbrojenie na Górnych Łużycach za czasów Luksemburgów. Stan badań
}

Niniejszy artykuł przybliża stan badań nad służbą wojskową rycerstwa i mieszczan Górnych Łużyc oraz jej uzbrojenia w czasach panowania Luksemburgów. Rozważania te obejmują nie tylko prezentację dorobku naukowego na tym polu, lecz także uzasadnienie zamiaru podjęcia tej tematyki. Praca ma charakter szkicu.

Pod względem ilościowym materiał źródłowy jest bogaty, choć pod względem jakościowym wygląda to mniej imponująco. Najbogatsze zbiory archiwalne znajdują się w Niemczech. Warte uwagi są też archiwalia w Polsce i w Czechach, choć nie są one pokaźne.

Najwięcej uwagi omawianemu zagadnieniu poświęcili niemieccy badacze, choć częstokroć problem znajdował się na uboczu głównych rozważań. Najbardziej wartościowe studia prowadzili Hermann Knothe i Richard Jecht, wybitni górnołużyccy historycy.

W Polsce problem nie jest szeroko rozpatrywany, choć na uwagę zasługują badania Mateusza Golińskiego i Roberta Hesia.

Mimo niezbyt rozwiniętych studiów dotyczących tego problemu stworzenie ewentualnej pracy na ten temat jest zasadne. Potrzeba ta jest dyktowana rosnącym zainteresowaniem Górnymi Łużycami oraz inspiracją dziełami wrocławskich mediewistów.

Słowa kluczowe: Górne Łużyce, Luksemburgowie, służba rycerska i mieszczańska, stan badań, uzbrojenie, Hermann Knothe, Richard Jecht

\section{SUMMARY}

\section{Michał Dudziński, Military service of knights and townspeople and their armament in Upper Lusatia during the Luxembourg times. State of research}

This article presents the state of research on the military service of knights and townspeople of Upper Lusatia and their armament during the Luxembourg reign. These considerations include not only the presentation of scientific achievements in this field, but also the justification of the intention to address this issue. The paper is a draft in nature.

In terms of quantity, the source material is rich, although in terms of quality it looks less impressive. The richest archive collections can be found in Germany. The archives in Poland and the Czech Republic are also noteworthy, although they are not very large.

Most attention was paid to this issue by German researchers, although the problem was often on the sidelines of main considerations. The most valuable 
studies were conducted by prominent Upper Lusatian historians Hermann Knothe and Richard Jecht.

In Poland, the problem is not widely considered, although the research by Mateusz Goliński and Robert Heś is worthy of attention.

Despite the fact that studies on this issue are not very well developed, it is justified to work on a potential publication on this subject. This need stems from the growing interest in Upper Lusatia and the inspiring works of medieval historians from Wrocław.

Keywords: Upper Lusatia, Luxembourg dynasty, military service of knights and townspeople, state of research, armament, Hermann Knothe, Richard Jecht

\section{PEЗЮME}

\section{Михал Дудзинский, Рыцарская и мещанская служба и вооружение ее воинов в Верхней Лужице во времена Люксембургов. Состояние исследования}

В статье описывается состояние исследований военной службы рыцарей и мещан Верхней Лужицы и их вооружения во времена правления Люксембургов. Автором статьи представлены не только уже существующие научные достижения по этой теме, но также и обоснования актуальности данной тематики. Статья имеет эскизный характер.

В количественном отношении исходный материал богат, хотя его качество не столь впечатляюще. Самые богатые архивные собрания находятся в Германии. Архивы в Польше и Чехии также заслуживают внимания, хотя они и столь объемны.

Больше всего внимания тематике данной статьи уделили немецкие ученые, хотя зачастую исследуемая проблема находилась не в центре их основного поля деятельности. Самые значимые исследования проводили Герман Кнот и Ричард Йехт, выдающиеся верхнелужицкие историки.

В Польше эта тема не рассматривалась столь подробно, однако исследования Матеуша Голинского и Роберта Гесиа заслуживают внимания.

Несмотря на недостаточное внимание к исследованиям по этой проблеме, их возможное появление довольно оправдано. Потребность в этом продиктована растущим интересом к Верхней Лужице и воодушевляющими работами вроцлавских медиевистов.

Ключевые слова: Верхняя Лужица, Люксембурги, рыцарская и мещанская служба, состояние исследований, Герман Кнот, Ричард Йехт 